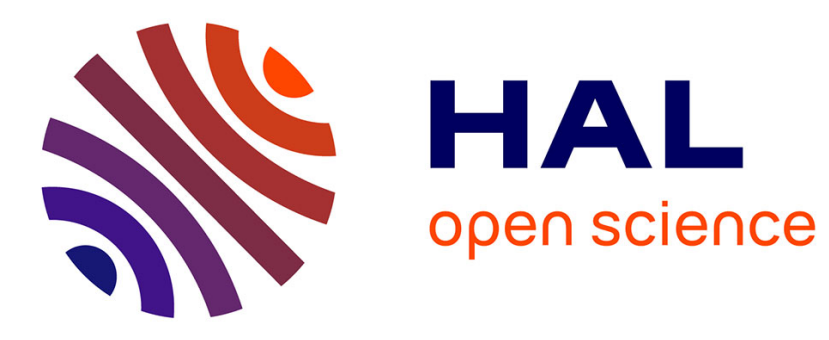

\title{
Microstructure variation and hardness diminution during low cycle fatigue of $55 \mathrm{NiCrMoV} 7$ steel Zhan-Ping Zhang, Yu-Hong Qi, Denis Delagnes, Gérard Bernhart
}

\section{To cite this version:}

Zhan-Ping Zhang, Yu-Hong Qi, Denis Delagnes, Gérard Bernhart. Microstructure variation and hardness diminution during low cycle fatigue of $55 \mathrm{NiCrMoV} 7$ steel. Journal of Iron and Steel Research International, 2007, 14 (6), pp.68-73. 10.1016/S1006-706X(07)60093-4 . hal-01715083

\section{HAL Id: hal-01715083 \\ https://hal.science/hal-01715083}

Submitted on 11 Jan 2019

HAL is a multi-disciplinary open access archive for the deposit and dissemination of scientific research documents, whether they are published or not. The documents may come from teaching and research institutions in France or abroad, or from public or private research centers.
L'archive ouverte pluridisciplinaire HAL, est destinée au dépôt et à la diffusion de documents scientifiques de niveau recherche, publiés ou non, émanant des établissements d'enseignement et de recherche français ou étrangers, des laboratoires publics ou privés. 


\title{
Microstructure Variation and Hardness Diminution During Low Cycle Fatigue of 55NiCrMoV7 Steel
}

\author{
ZHANG Zhan-ping ${ }^{1}, \quad$ QI Yu-hong ${ }^{1}$, DELAGNES Denis ${ }^{2}, \quad$ BERNHART Gérard ${ }^{2}$ \\ (1. Electro-Mechanics and Materials College, Dalian Maritime University, Dalian 116026, Liaoning, China; 2. Research \\ Center on Tools, Materials and Processes, Ecole des Mines d'Albi-Carmaux, 81013 Albi CT cedex 09, France)
}

\begin{abstract}
The influence of temperature and hardness level on the cyclic behavior of $55 \mathrm{NiCrMoV} 7$ steel, and the microstructure variation and hardness diminution during low cycle fatigue behavior were investigated. By means of SEM and XRD, the modality of carbides and the full-width half-maximum (FWHM) of martensite (211) [M(211)] of Xray diffraction spectrum in fatigue specimen were studied. The results showed that the cyclic stress response behavior generally showed an initial exponential softening for the first few cycles, followed by a gradual softening without cyclic softening saturation. The fatigue behavior of the steel is closely related to the hardness level. The hardness diminution and the variation of half-width $\mathrm{M}(211)$ are remarkably influenced by the interaction between the cyclic plastic deformation and the thermal loading when the fatigue temperature exceeds the tempering temperature of the steel.

Key words: low cycle fatigue; $55 \mathrm{NiCrMoV} 7$ steel; microstructure; hardness; half-width
\end{abstract}

Hot-work tool steels are widely used in various heat-treatment (i. e. tempering conditions) states to obtain the mechanical properties requested by the industrial application, like hot forging, casting, hotrolling, extrusion, where the steel endures cyclic thermal and mechanical loads ${ }^{[1]}$. Some of the investigations indicate that cyclic plasticity is responsible, in parallel to wear and abrasion, for the tool limit lifetime $^{[2,3]}$. Nevertheless, the fatigue behavior of steel not only depends on the fatigue test conditions such as temperature, frequency, strain amplitude, stress ratio, etc., but also on the microstructure, which can be controlled by means of heat treatment.

Some investigations have shown that the interface temperature between the die and the work-piece surpasses the tempering temperature of the steel. In such conditions, the steel can be subjected to a continuous evolution of microstructure and mechanical properties during service. It is therefore of great importance to derive an anisothermal constitutive model, which may be able to take into account the great range of strain rates, the temperature variations, as well as the effect of ageing. The ultimate aim of such an approach, which consists in understanding the interactions, between the microstructure and properties, is to ensure a good prediction of fatigue behavior to optimize tool design and to derive a more realistic life prediction model. For this goal, some models have been investigated during the last years in the case of stable microstructure $\mathrm{e}^{[4-7]}$, and more recently, an anisothermal cyclic behavior model that takes into account the ageing (tempering) effect of a martensitic tool steel was proposed by $\mathrm{ZHANG}^{[8,9]}$. These models have to be developed based on the ex perimental results.

This study reports the low cycle fatigue behavior and the microstructure evolution of hot-work tool steel with four different initial tempering treatments.

\section{Experiments}

The material investigated is $55 \mathrm{NiCrMoV} 7$ hot-

\footnotetext{
Foundation Item; Item Sponsored by Scientific Research Foundation for Returned Overseas Chinese Scholars, State Education Ministry (2004176)

Biography: ZHANG Zhan-ping(1963-), Male, Doctor, Professor; E-mail; zzp@newmail. dlmu. edu. cn; Revised Date: April 3, 2006
} 
work tool steel with a chemical composition (mass percent, $\%$ ) of $\mathrm{C} 0.56, \mathrm{Ni} 1.7, \mathrm{Cr} 1.0, \mathrm{Mo} 0.5, \mathrm{~V}$

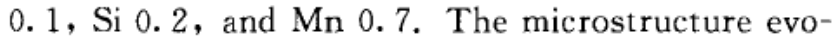
lutions of the steel were investigated with SEM (PHILIPS-XL30) and XRD (D/max-IIIa). The XRD spectrum was measured in continuous scanning mode, using CoK $\alpha$ line at $35 \mathrm{kV}$ and $30 \mathrm{~mA}$. The recording was done for scanning angle ranging from $20-120\left(^{\circ}\right)$ at a scanning speed of $4\left(^{\circ}\right) / \mathrm{min}$. The $\mathrm{XRD}$ spectrum and data were treated by Powder $\mathrm{X}^{[10]}$. The quenched microstructure contains martensitic laths and the tempered one consists of carbides and martensite. To investigate the effect of tempering on the cyclic fatigue behavior, samples were manufactured with four hardness levels for standard industrial applications. The heat-treatment conditions and the hardness of the steel are reported in Table 1.

The isothermal fatigue behavior of the steel for each tempering state was investigated in the 20 $600{ }^{\circ} \mathrm{C}$ range. All fatigue tests were carried out with an MTS 810 closed-loop servo-hydraulic testing machine and a Teststar $I^{\mathrm{TM}}$ controller connected to a personal computer. The samples were subjected to total strain fatigue tests at the following temperatures: $20^{\circ} \mathrm{C}, 300{ }^{\circ} \mathrm{C}, 400{ }^{\circ} \mathrm{C}, 500{ }^{\circ} \mathrm{C}$, and $600{ }^{\circ} \mathrm{C}$. The round specimens were mounted in water-cooled grips and heating was achieved with a $6 \mathrm{~kW}$ induc tion generator. The temperature was controlled in the middle of the sample by mechanically applied thermocouples ${ }^{[7]}$. The strain was recorded using a $12 \mathrm{~mm}$ gage length contact extensometer with alumina rods. Cyclic tests were started after heating at a rate of $200{ }^{\circ} \mathrm{C} / \mathrm{min}$ and a temperature stabilization of $75 \mathrm{~s}$.

The total strain amplitude is fixed to $\pm 0.8 \%$ during all low cycle fatigue tests, whereas the strain rate is $10^{-2} \mathrm{~s}^{-1}$. The number of cycles $(N)$ was selected to reach a near constant cumulative plastic strain close to $4 \mathrm{~mm} / \mathrm{mm}$ (i. e. without rupture) for all tests. The hardness was measured using a Buehler ${ }^{\circledR} \mathrm{MI}-$ CROMET $^{\circledR} 2001$ type microhardness tester. Thirty

Table 1 Quenching and tempering conditions of fatigue samples

\begin{tabular}{ccccc}
\hline Tempering temperature $/{ }^{\circ} \mathrm{C}$ & 350 & 460 & 560 & 600 \\
\hline Tempering time/h & 2 & 2 & 2 & 2 \\
Hardness (HVO. 2) & 570 & 505 & 457 & 374 \\
Hardness (HRC) & 50 & 45.5 & 42 & 35 \\
\hline
\end{tabular}

Note: Quenching condition: austenizing at $850^{\circ} \mathrm{C}$ for $1 \mathrm{~h}$, quenching in vacuum indentations were performed on each sample with $2 \mathrm{~N}$ load. The mean value was considered as the hardness result.

\section{Low Cycle Fatigue Behavior}

\section{1 Typical experimental results}

The typical cyclic behavior of the $55 \mathrm{NiCrMoV} 7$ steel is shown in Fig. 1 by the $\Delta \sigma / 2-N$ curves. The results indicate that at $300^{\circ} \mathrm{C}$ and $20^{\circ} \mathrm{C}$, the curves are clearly separated by the stress amplitude and the hardness level [Fig. 1 (a)]: the semi-stress amplitude increases when the hardness increases, whereas at $500{ }^{\circ} \mathrm{C}$ and $600{ }^{\circ} \mathrm{C}$, some curves cannot be easily distinguished. Three of these curves are very close in Fig. 1 (b) and the curve of the HRC 50 sample is even lower than that of the HRC 45.5 sample. This phenomenon seems surprising and will be discussed in the following sections. As seen, the semi-stress amplitude decreases with the number of cycles. The steel manifests the behavior of cyclic softening under the loading of cyclic strain regardless of the hardness of the steel and the test temperature. This softening can be divided into two phases, which are the rapid softening phase during the initial cycles followed by the slow softening phase. The former is generally explained by the exponential change of the density and the structure of dislocations. Generally speaking, the latter is related to the modification of the dislocation sub-structure and carbide in the steel by the action of cyclic load.

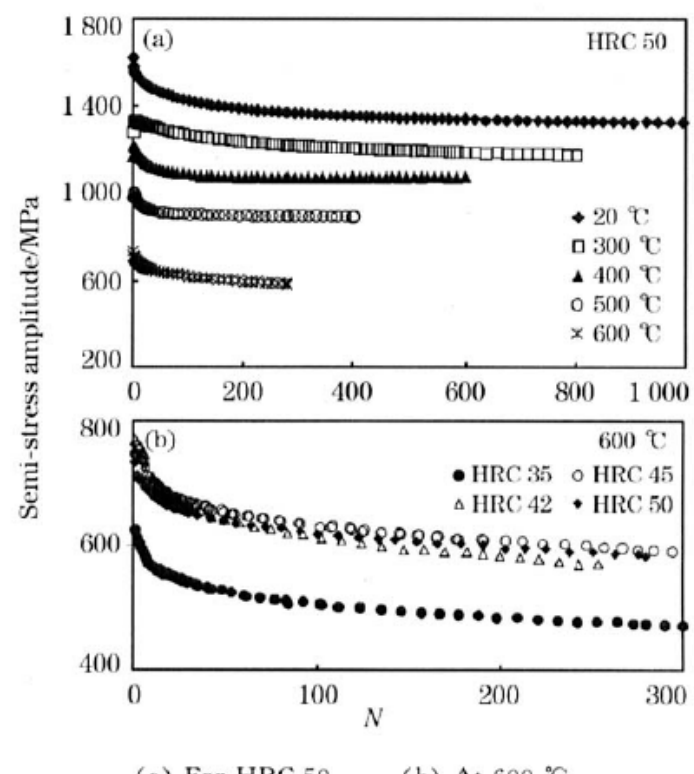

Fig. 1 Typical $\Delta \sigma / 2-N$ curves of $55 \mathrm{NiCrMoV7}$ steel at $\Delta \varepsilon_{t}= \pm 0.8 \%$ 


\section{2 Temperature, hardness, and cyclic behavior}

\section{2. 1 Maximum stress}

The variation of maximum stress with the test temperature is shown in Fig. 2. For each hardness level, the maximum stress decreases with the test temperature. The values of the maximum stress of the steel with higher hardness level are even smaller than that of the steel with lower hardness level at elevated temperature. Fig. 3 shows the evolution of maximum stress with the temperature difference between fatigue and tempering of test steel. Fig. 3 can be divided into two parts; for the left part, the difference is negative, and the maximum stress decreases linearly with the difference for each level of hardness; at the right part of Fig. 3 , when the difference is positive, the maximum stress decreases more violently because of the interaction of temperature and stabilization of steel. It is obvious to relate with the evolution of the steel, i. e. the thermal ageing effect.

\section{2. 2 Intensity of cyclic softening}

Fig. 4 presents the evolution of the intensity of softening at cumulative plastic strain $p=4$ with test temperature for HRC 35 and HRC 42 specimen. As seen, the intensity of softening $\left[(\sigma / 2)_{\max }-(\Delta \sigma / 2)_{p=4}\right]$ at $p=4$ increases with the increase of test temperature

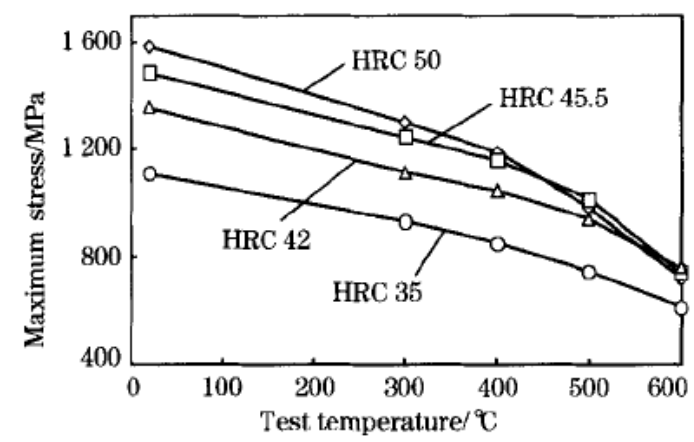

Fig. 2 Maximum stress of steels vs test temperature

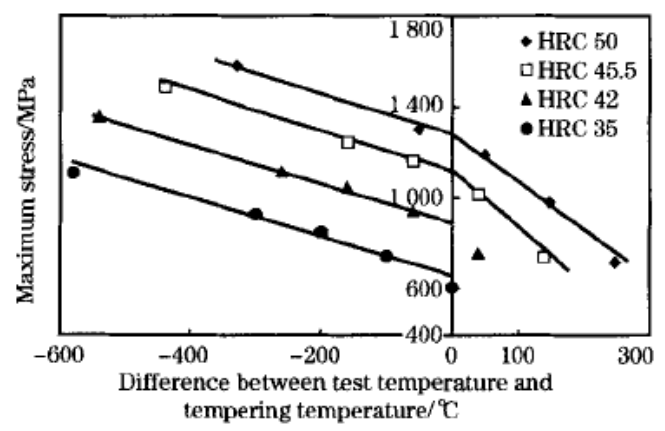

Fig. 3 Maximum stress vs difference between test temperature and tempering temperature

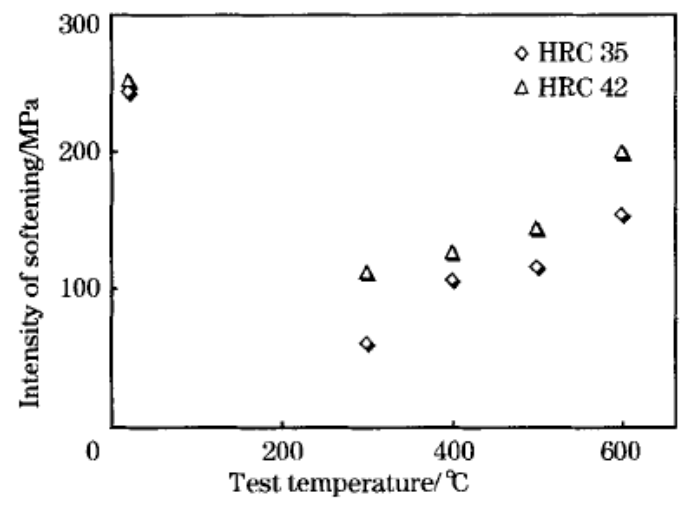

Fig. 4 Intensity of softening vs test temperature

from $300{ }^{\circ} \mathrm{C}$ to $600{ }^{\circ} \mathrm{C}$, and rises with hardness at each temperature. The value reaches up to $200 \mathrm{MPa}$ at $600{ }^{\circ} \mathrm{C}$ for HRC 42 sample. However, the maximum intensity of softening appears at $20{ }^{\circ} \mathrm{C}$ for each hardness specimen.

\subsection{Discussion}

Fig. 5 shows the relation between the hardness of the steel tempered and the semi-stress amplitudes at $p=3$. It is clear that the semi-stress amplitudes increase linearly with the hardness of steel tempered at room temperature and at $300{ }^{\circ} \mathrm{C}$. When the test temperature is equal to or is greater than $400{ }^{\circ} \mathrm{C}$, the semi-stress amplitudes do not follow the former linear relation in the domain of the higher hardness level. This "unusual" phenomenon becomes more visible in Fig. 6 , in which the maximum stresses during first loading are drawn with hardness. What is the root cause for this "unusual" phenomenon? Further analyses indicated that all points diverged its linearity happened when the test temperature is equal to or is greater than the tempering temperature of the steel. This indicates that the steel is not stable during fatigue, and the hardness and the microstructure can be modified by thermal cycle when the steel is subjected to temperatures equal to or higher than the tempering temperatures, even for short times (a temperature stabilization of $75 \mathrm{~s}$ before cycling). It was testified by some investigations on the evolution of hardness after cyclic fatigue tests and equivalent ageing tests ${ }^{[8]}$. As a consequence, the tempered hardness cannot correctly represent the cyclic behavior of the steel when it is subjected to ageing. It is necessary to determine an appropriate parameter for correctly describing such an influence of temperature in a cyclic constitutive model. Corresponding investigations will be reported in another article. 


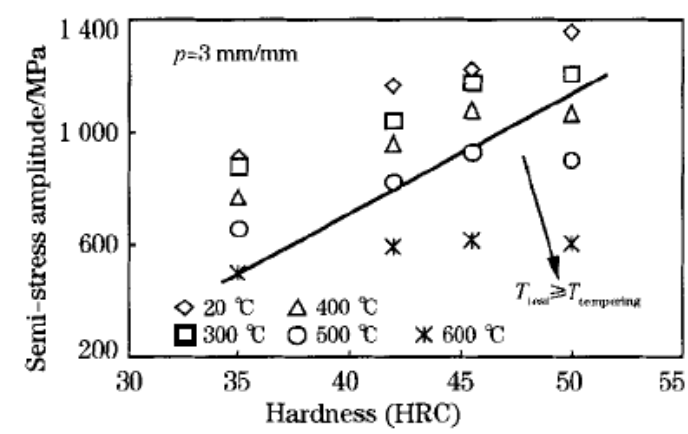

Fig. 5 Semi-stress amplitude at $p=3$ vs hardness

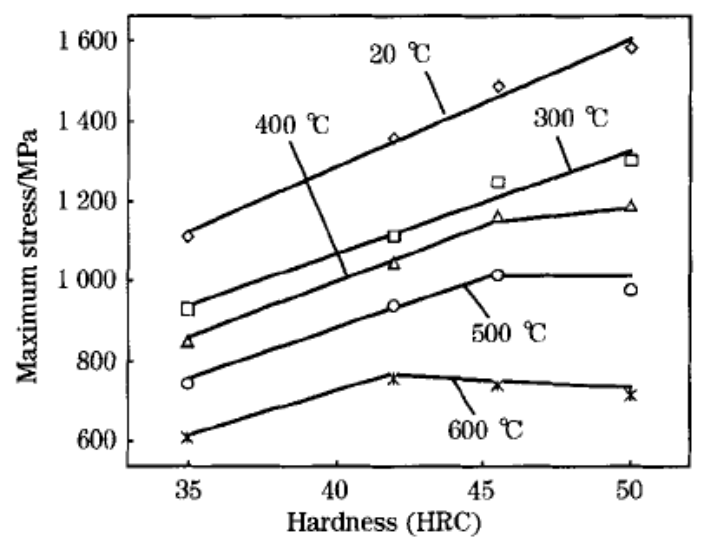

Fig. 6 Maximum stress of steel $v s$ hardness

\section{Hardness Diminution and Microstructure Variation During Test}

As above-mentioned, the cyclic behavior of the steel was strongly related to the temperature and hardness, and obviously to the fatigue-aging interaction. The hardness changes of the test specimens are shown in Fig. 7 with respect to the difference between the test and tempering temperatures. When the test temperature is lower than the initial tempering temperature, the absolute value of hardness diminution is low and there is no change with the temperature difference and the initial hardness level at room temperature. However, the hardness diminution is considerably higher and it increases more rapidly when the temperature difference is positive. It can even decrease to HV 225 for the HRC 50 sample tested at $600{ }^{\circ} \mathrm{C}$; here, the hardness after test is close to $40 \%$ of the initial hardness. To investigate the role of mechanical loads and thermal aging on the evolution of the steel during test, some equivalent tempering tests were carried out, and the tempering temperature and time were selected corresponding to that of the relevant fatigue test (ref. Table 2). The

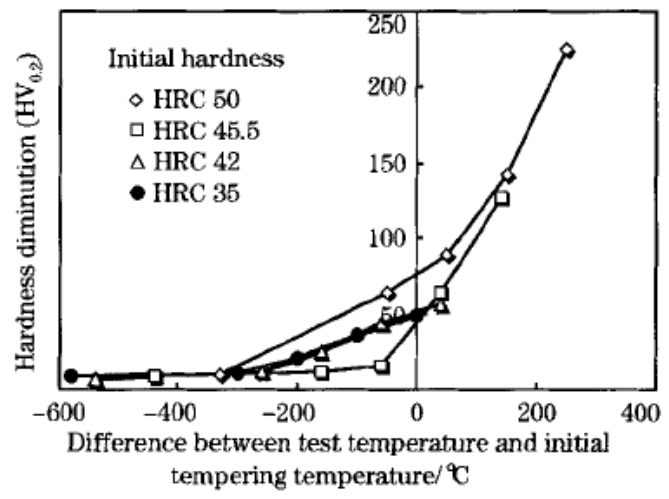

Fig. 7 Relation between absolute value of hardness diminution and temperature difference

hardness measured and the full-width half-maximum (FWHM) of martensite (211) $[\mathrm{M}(211)]$ are reported in Table 2.

Compared with the initial tempered state, both the hardness and the FWHM of M(211) decreased during the fatigue test and during equivalent tempering. During tempering/aging of steel quenched, because of the phase transformation promoted by diffusion from an unstable state to a quasi equilibrium state, martensite with higher density dislocations is transformed to ferrite with lower density dislocations and globular carbides. Therefore, the hardness and FWHM of M(211) decrease during tempering/ aging. Further analysis indicated that both the hardness diminution and the FWHM diminution during fatigue test could be divided into two parts, one is induced by thermal effect/aging and another is caused by mechanical cyclic loads/fatigue. The total and the thermal hardness diminution increase with the test temperature, and the total hardness diminution owes entirely to the mechanical loads at room temperature (Fig. 8). Thermal hardness diminution even occurs at test temperature $\left(300{ }^{\circ} \mathrm{C}\right)$ that is lower than the initial tempering temperature $\left(350{ }^{\circ} \mathrm{C}\right)$. It means that the steel may be aged even if the temperature in service is lower than the initial tempering temperature of the steel. As known from the hardness evolution, the total FWHM diminution fluctuates with the temperature difference in a small bound. The thermal proportion in the total FWHM diminutions increases, but the mechanical proportion decreases with the temperature difference when the test temperature is higher than the initial tempering temperature (Fig. 9). The different evolutions between the hardness diminution and the FWHM 
Table 2 Hardness and FWHM of M(211) for HRC 50 specimens

\begin{tabular}{|c|c|c|c|c|c|c|c|c|}
\hline \multirow{3}{*}{$\begin{array}{l}\text { Initial tempering } \\
\text { temperature } /{ }^{\circ} \mathrm{C}\end{array}$} & \multicolumn{8}{|c|}{ Fatigue test } \\
\hline & \multirow{2}{*}{$\begin{array}{c}\text { Temperature / } \\
{ }^{\circ} \mathrm{C}\end{array}$} & \multirow{2}{*}{$\begin{array}{c}\text { Duration/ } \\
\mathrm{s}\end{array}$} & \multicolumn{3}{|c|}{ Hardness $\left(\mathrm{HV}_{0.2}\right)$} & \multicolumn{3}{|c|}{ FWHM of M(211) } \\
\hline & & & $\begin{array}{c}\text { Before } \\
\text { test }\end{array}$ & $\begin{array}{c}\text { After } \\
\text { test }\end{array}$ & $\begin{array}{c}\text { Total } \\
\text { diminution }\end{array}$ & $\begin{array}{c}\text { Before } \\
\text { test }\end{array}$ & $\begin{array}{c}\text { After } \\
\text { test }\end{array}$ & $\begin{array}{c}\text { Totel } \\
\text { diminution }\end{array}$ \\
\hline 350 & 20 & 6754 & 570 & 560 & 10 & 1. 2265 & 0.7307 & 0.4958 \\
\hline 350 & 300 & 5474 & 581 & 517 & 64 & 1. 2265 & 0.6637 & 0.5628 \\
\hline 350 & 400 & 4799 & 580 & 491 & 89 & 1.2265 & 0.6429 & 0.5836 \\
\hline 350 & 500 & 4122 & 584 & 442 & 142 & 1. 2265 & 0.6886 & 0.537 .9 \\
\hline 350 & 600 & 3458 & 584 & 359 & 225 & 1. 2265 & 0.5601 & 0.6664 \\
\hline \multirow{3}{*}{$\begin{array}{l}\text { Initial tempering } \\
\text { temperature } /{ }^{\circ} \mathrm{C}\end{array}$} & \multicolumn{8}{|c|}{ Equivalent tempering } \\
\hline & \multirow{2}{*}{$\begin{array}{c}\text { Temperature/ } \\
{ }^{\mathrm{C}}\end{array}$} & \multirow{2}{*}{$\begin{array}{c}\text { Duration/ } \\
\mathrm{s}\end{array}$} & \multicolumn{3}{|c|}{ Hardness $\left(\mathrm{HV}_{0.2}\right)$} & \multicolumn{3}{|c|}{ FWHM of M(211) } \\
\hline & & & $\begin{array}{c}\text { Before } \\
\text { test }\end{array}$ & $\begin{array}{c}\text { After } \\
\text { test }\end{array}$ & $\begin{array}{c}\text { Thermal } \\
\text { diminution }\end{array}$ & $\begin{array}{c}\text { Before } \\
\text { test }\end{array}$ & $\begin{array}{c}\text { After } \\
\text { test }\end{array}$ & $\begin{array}{l}\text { Thermal } \\
\text { diminution }\end{array}$ \\
\hline 350 & 20 & 6760 & 570 & 570 & 0 & 1.2265 & 1.2265 & 0 \\
\hline 350 & 300 & 5520 & 581 & 567 & 14 & 1. 2265 & 1. 2768 & -0.0503 \\
\hline 350 & 400 & 4800 & 580 & 541 & 39 & 1. 2265 & 1. 1497 & 0.0768 \\
\hline 350 & 500 & 4140 & 584 & 494 & 90 & 1. 2265 & 0.8376 & 0.3889 \\
\hline 350 & 600 & 3480 & 584 & 446 & 138 & 1.2265 & 0.5759 & 0.6506 \\
\hline
\end{tabular}

diminution are derived from that FWHM of M(211) is only a reflection of irregularity of the crystal lattice, and the hardness change involves not only from irregularity of crystal lattice but also from other causes for morphology and size of carbides, etc. SEM observations showed that with the diminution of FWHM, the morphology and the dimensions of carbides in the steel varied during the fatigue test. As seen in Fig. 10, it is evident that compared with the microstructure tempered at $600{ }^{\circ} \mathrm{C}$ of the steel

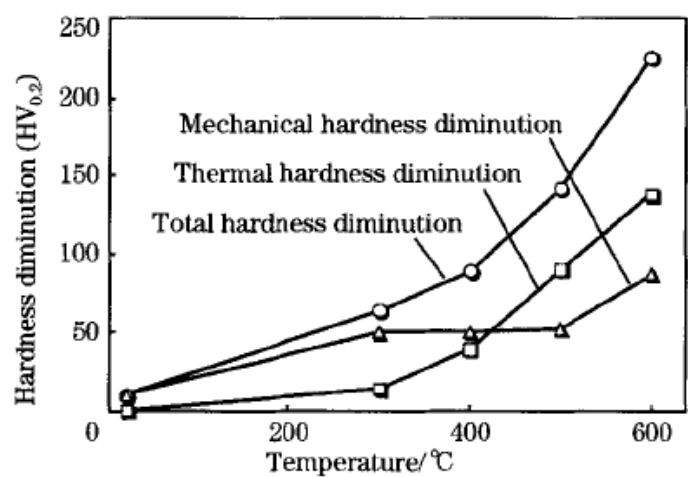

Fig. 8 Hardness diminutions for specimen (HRC 50) during fatigue test

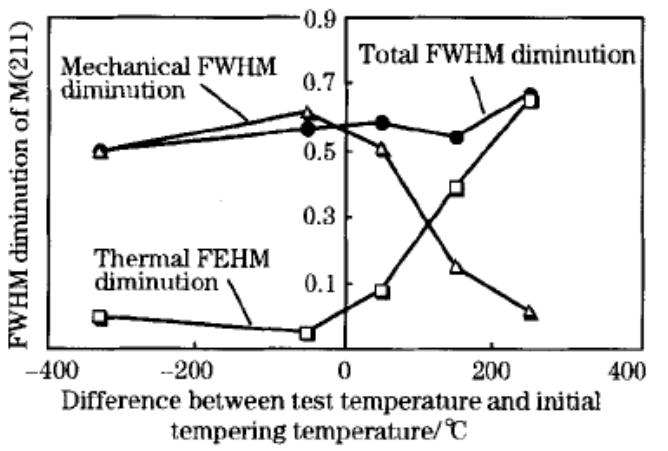

Fig. 9 FWHM diminutions for specimen (HRC 50) during fatigue test

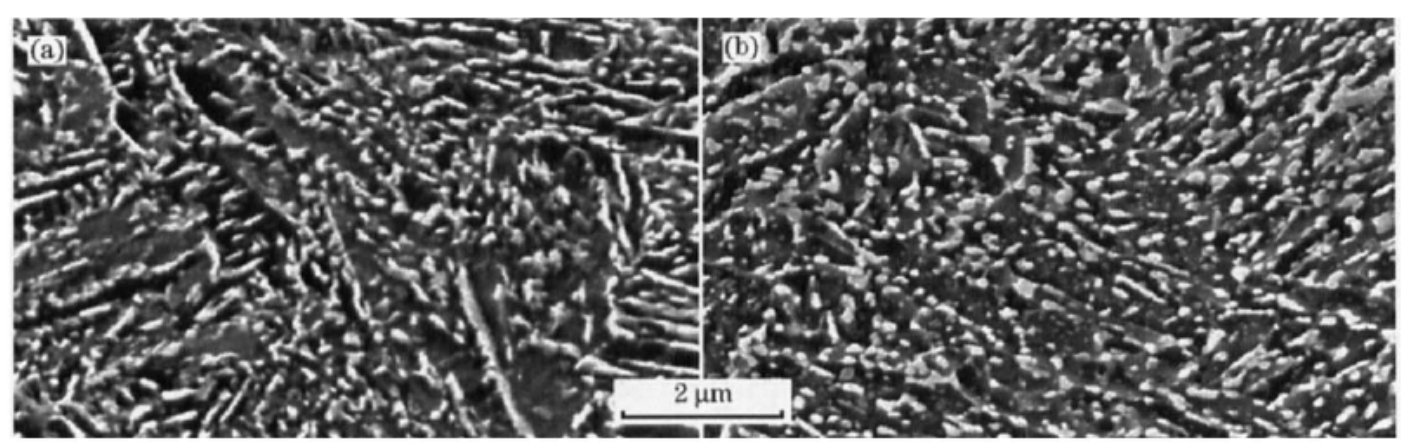

(a) Before fatigue;

(b) After fatigue at $600{ }^{\circ} \mathrm{C}$

Fig. 10 SEM morphology of carbides in steel 
[Fig. 10 (a)], the carbides become larger and more round, but the carbides' sum decreases [Fig. 10 (b)].

\section{Conclusions}

(1) The steel manifests the behavior of cyclic softening under the loading of cyclic strain regardless of the hardness of the steel and the test temperature.

(2) The cyclic behavior of the steel was strongly related to the temperature and hardness, and obviously to the fatigue-aging interaction.

(3) Both hardness and FWHM diminution during fatigue test can be divided into two parts, one is induced by the thermal/aging effect and the other is caused by the mechanical cyclic/fatigue loads. The former occurs when the test temperature is more than the initial tempering temperature and it augments with the difference between the test temperature and the initial tempering temperature.

\section{References:}

[1] Bernhart G, Moulinier G, Brucelle O, et al. High Temperature Low Cycle Fatigue Behaviour of a Martensitic Forging Tool Steel [J]. Int J of Fatigue, 1999, 21(2): 179-186.

[2] Bournicon C. Sollicitations et Modes D'endommagement des Outillages de Forge à Chaud [J]. Traitement Thermique, 1991, 246: 70-77.
[3] Delagnes D. Isothermal Fatigue Behaviour and Lifetime of a $5 \% \mathrm{Cr}$ Hot Work Tool Steel Around the LCF-HCF Transition [D]. Paris, France: ENSMP, 1998.

[4] Zhang Z, Delagnes D, Bernhart G. Stress-Strain Behaviour of Tool Steels Under Thermo-Mechanical Loadings: Experiment and Modeling [A]. Franz Jeglitsch, Reinhold Ebner, Harald Leitner, eds. Tool Steels in the Next Century, Proceedings of the 5 th International Tooling Conference [C]. Leoben: University of Leoben, 1999. 205-213.

[5] Velay V, Bernhart G, Zhang Z, et al. Cyclic Behaviour Modeling of Martensitic Hot Work Tool Steels [A]. Biallas G, Maier $\mathrm{H} \mathrm{J}$, Hahn O, et al, eds. High-Temperature Fatigue, Proceedings CAMP2002 [C]. Bad Lippspringe: Paderborn, 2002. 6475.

[6] Bernhart G, Choi B G, Zhang Z, et al. Single Specimen Methodology for Elasto-Visco-Plastic Fatigue Model Identification of Martensitic Steels [A]. Miannay D, Costa P, Francois D, et al, eds. Advances in Mechanical Behaviour, Plasticity and Damage [C]. Oxford, Elsevier, 2000, 1077-1082.

[7] Zhang Z, Delagnes D, Bernhart G. Anisothermal Cyclic Plasticity Modelling of Martensitic Steels [J]. Int J of Fatigue, $2002,24(6)$ : 635-648.

[8] Zhang Z. Anisothermal Cyclic Behaviour Modelling With Taking Account of Tempering Effect of a Martensitic Tool Steel $55 \mathrm{NiCrMoV} 7$ [D]. Paris, France: ENSMP, 2002.

[9] Zhang Z, Delagnes D, Bernhart G. Tempering Effect on Cyclic Behaviour of a Martensitic Tool Steel [A]. Jens Bergstrom, eds. The Use of Tool Steels: Experience and Research, Proceedings of the 6th International Tooling Conference [C]. Karlstad: Karlstad University, 2002. 573-589.

[10] Dong C. PowderX User Manual [M]. Beijing: Institute of Physics, Chinese Academy of Sciences, 1998. 